\title{
FROM FRAGMENTED CERTAINTY TO POST COVID PARADIGM: RESILIENT MODALITIES BASED ON GROUP INTERACTION SUPPORTED BY TECHNOLOGIES
}

\author{
Maria Annarumma, Felice Corona \\ University of Salerno, Italy \\ E-mail: mannarumma@unisa.it, fcorona@unisa.it
}

\begin{abstract}
It is no longer the age of good practices and certainties, of well-made projects and great ideologies but it is the age of dynamic, creative and flexible strategies. In the midst of the crisis, we have acquired at least one certainty: No one saves himself alone. Reluctantly we understand that it is not a question of being strong or weak, "winning" or "losing", but that we exist through this existential fragility that allows us to affirm our belonging to the community.

The objective of this theoretical analysis is based on the analysis of the relationship between resilience and collaborative activity based on technologies. This analysis highlights that resilient action is activated thanks to the collaboration between the actors of the exceptional event that through technology redefine environmental boundaries, generating a resilient informal context.
\end{abstract}

Keywords: collaborative activity, post covid paradigm, resilient modalities, theoretical analysis.

\section{Introduction}

Three are the words that more than others have marked our lives during this last year. The first word is "uncertainty", linked to the sudden change of events and to the difficulty or inability to predict our future life that we know will inevitably change. The second word is "immunity", linked to the possibility of developing antibodies and creating a vaccine, or associated with the term "herd". Both words scare us. The first makes us dismayed about our future, the second refers to a natural selection that is equally scary, because in the meantime, many people succumb.

The third word is "lockdown" used over 250 million times, compared to just 4,000 times the previous year. An absolute record recorded by Collins which awarded it the top of the ranking of the most used words of the year.

The publishing house lexicographers explained that "it is a unifying experience for billions of people around the world who have collectively had to play their part in the fight against the spread of Covid-19". We are talking about the majority of the population defending themselves and others through the only possible resource: Social distancing and lockdown, and who passively witness the collective drama narrated by the media.

These simple reflections are at the basis of that feeling of waiting that it is living in these suspended days, while outside the drama is staged, and we are watching helplessly. We are all victims of 
a collective trauma from which we have to immunize ourselves. Paraphrasing Freud, a trauma is an event that strikes the person in a violent way and towards which he has not yet generated antibodies. It would be interesting to find - always using Freudian language - psychological antibodies, to reach a psychological immunity capable of processing uncertainty and protecting ourselves from the fear of tomorrow and change, while waiting for medicine to take its course.

Within this interpretative framework the epistemologist Morin offers us a possible path, that is, a psychological immunity that protects us from those post-traumatic disorders due to isolation, fear of the present and concern for the future.

Morin (1993) offered us the path of uncertainty. Within his interpretation of complex systems, he states that at present we no longer have tools that guarantee objectivity. Reality is, therefore, a particular alchemy between order and chaos which he calls complexity (Morin, 2008). If we observe the virus in a systemic way, we will discover that its strength lies not so much in lethality as in its speed, in its ability to collapse the social and health system, to finally reach a violent impact on the world economic system. It is facing the Butterfly effect (Lorenz, 215), that is, when small variations in the initial conditions produce large variations in the long-term behaviour of a system. Although the contagion itself is a linear, mechanical, cause-effect concept, the impact on the system is devastating.

We have already witnessed, through the narratives of the past, epochal turning points that have determined a break with what tradition had accustomed us to thinking and knowing. In 1979 Lyotard published The Postmodern Condition in which the thesis according to which modernity has reached its fulfilment is presented. Referring to a historical phase in which we are witnessing the fragmentation of absolutist paradigms and ideologies on which the world was based as foundations of stability.

The great frames of reference that have dissolved and have not been replaced by equally strong and unitary constructions. So much so that the postmodern era was characterized by a fragmented, polymorphous and multiple vision of reality, Lyotard in an interview with the Italian Cultural Institute in 1994 declared: "What I am experiencing is an upsetting season, crossed by changes very rapid, which leave the conditions of stability standing for very short stretches, the space of a morning overwhelmed by scientific and technological transformations" (Lyotard, 1979).

The end of the great systems and the affirmation of a multiplicity of languages leads to a loss of centralization in the organization of the State and therefore of the social and economic system, therefore we are witnessing a continuous process of atomization, many systems and subsystems (Luhmann, 2005).

Now the world again faced with a scenario of great rupture of socio-cultural, political and scientific schemes, which although complex had created a condition of stability in the underlying instability (Baumann, 2000).

From now on, nothing will be the same again, it seems to be a cliché, but it is the only certainty there is. History offers us another paradigm shift this time post covid, a change caused by a virus that has shaken the life of the planet and all its inhabitants, highlighting an underlying truth: The fragility of the world system.

\section{Theoretical Framework for Future Developments}

This study is a theoretical analysis that aims to highlight that there is a relationship between resilience and collaborative activity based on technologies. This observation highlights that resilient action is activated thanks to the collaboration between participants who share a life difficulty that in this historical phase, connected to the pandemic condition, technology becomes the link between the actors and the exceptional event.

Specifically, the world of technology with its tools (social networks, instant messaging and platforms and so on) redefines environmental boundaries, generating a resilient informal context in which it is possible to create an alternative solution to current difficulties through digital narration.

We live in a participatory culture which contrasts with the old notions of passive media viewer. New media participants interact with each other according to a new set of rules that none of us fully understand (Jenkins, 2007, p. 4). 
According to Jenkins, convergence occurs within "the brains of individual participants and through their social interactions with others. Everyone builds their own personal story from pieces Vol. 14, No. 2, 2020 of information extracted from the flow of the media and transformed into resources through which we give meaning to our daily life.

None of us can know everything; each of us knows something; and we can put the pieces together if we pool our resources and pool our skills (Jenkins, 2007, p. 18). Collective intelligence (Lèvy, 1996) can be seen as an alternative source oriented this time to improving the quality of life.

From this pandemic condition it emerges even more strongly that there is a power that arises from our daily interactions within the culture of convergence. The creation of collaborative groups and the possibility of improving the quality of life is starting to change the ways in which education, politics, law, religion, family, and advertising operate.

Entertainment content is not the only thing that flows on multiple multimedia platforms, our lives, relationships, memories, fantasies, desires also flow through media channels. All of this generates the culture of convergence, where old and new media collide, where the power of the media producer and the power of the media consumer interact in unpredictable and creative ways. The culture of convergence is the future, it draws new perspectives in all fields of knowledge and understanding (Jenkins, 2007, p. 18).

And this is a crucial aspect that has in itself new development possibilities for research. Starting from these considerations and analyses, if there is a possibility of addressing the difficulties whatever they may be, technologies, if well designed, can be a valid therapeutic tool. A good example can be Sygmund application designed by De Carlo, it arises from the awareness that applications play an important role in everyday life, there is an app for every activity from fitness to cooking, from games to education, from prayer to pop music. Sygmund is an app in which anyone can connect and find a psychologist with whom it is possible to talk via video call, at any time and from anywhere, making all the main functions extremely user-friendly.

An innovative modality that comes from grassroot culture. It teaches us that using a dedicated app at a particular moment in life can be a potential tool to improve the quality of life and well-being. It is evident that technology once again guides us but without the human creativity all this will be impossible.

\section{The Epochal Change and the Post Covid Paradigm}

The term emergency has always been associated with the concept of crisis and uncertainty. Crisis of change, values and consequent choices, crisis of strategies and personal crises, where the person, and the relationships between people are the condition and opportunity on which society, institutions and organizations all, without exception, are based.

The crisis according to Einstein (1955) is the best blessing that can come to people and countries, because the crisis brings progress. It is from the crisis that inventiveness, discoveries and great strategies are born. Without it there are no challenges, and without challenge life is a routine. It is from the crisis that the best of each one emerges, since without it every wind is a caress. We definitively end with the only crisis that threatens us, that is, the tragedy of not wanting to fight to overcome it.

Einstein's relativism, quantum physics, the mapping of the human genome, modern philosophies of science such as Popper's falsificationism (1972) tell us that a scientific statement "is true until it is falsified". Knowledge is not a simple sum of certain facts, but that truth and certainty are true until proven otherwise. In short, there is always a certain margin of uncertainty.

Within this framework of reality that contemplates uncertainty as a paradigm, Morin proposes a paradigm shift as a passage from the idea of an intelligence that pursues objectives trying to avoid error to the idea of an intelligence that adopts the strategy of error as its own modality of knowledge, accepting the uncertainty as a basic element: From a psychological point of view, accepting uncertainty means living in change.

In recent decades, psychology has treated the theme of change as a fundamental element for the emancipation of man. For the old psychoanalysis of Freudian memory and the old epistemologies, it remains a private fact, a cure for a trauma, a pathology. 
Conversely, in Rogers' vision of man (1980) we are dealing with an organism that is always motivated, is always intent on something, [...] a tendency towards completion, actualization, conservation and improvement of the organism. According to this approach, individuals actively respond to the stimuli of the environment by trying to satisfy their needs even when they face discomfort and pain. It is easy to observe this spontaneous process when the person perceives a possibility of choice which, if properly symbolized, becomes proactive, that is, oriented towards the peculiarity of this world historical phase that those who engage in a helping relationship (psychologists, social workers, pedagogues) are, just like the others, part of the system. In short, the observing system and the observed system are intrinsically intertwined: The supervisor and the supervisee linked by common interests. There is no longer a privileged point of view, a setting that allows the right dimension. As McWilliams (2020) says about the coronavirus: «The most difficult thing to deal with psychologically is the fact that the fear of the coronavirus is not neurotic anxiety, and the anxiety about its damage is not neurotic depression. I can help patients when their real fears and losses are complicated by their idiosyncrasies and vulnerabilities, but I cannot reduce emotional suffering that is grounded in reality».

\section{Shifting from the Biological to the Psychological Immunity through Collaboration and Technology}

Social life in the aftermath of disaster fulfils many of the essential human needs that are missing in the everyday life of modern societies. "Disasters are not only characterized by death, destruction, disintegration, and disease, they also provide conditions for vitality, reconstruction integration, growth and health. A consistent focus on the therapeutic features of disasters and disaster adaptations may lead us not only to a better understanding of this form of crisis but may also contribute to our knowledge of the essential conditions for mental health and effective social therapy in everyday life" (Fritz 1996, p. 19).

Today, with the experience of the Covid 19 pandemic, resilient modalities based on group interaction and supported by technologies have emerged. This partly recalls Rogers's studies on the importance of interacting with other people who share the same difficulty. Specifically, "the Encounter Group tends to enhance the growth of the person and the development and improvement of communication and interpersonal relationships, through a process of direct experience" (Rogers, 1976, p. 11). It improves interpersonal relationship skills and soothes loneliness. It also makes people more flexible, puts in touch with inner needs and feelings, improves ability to express ourselves.

Rogers talks about self-realization and personal power in the belief that everyone by nature always goes towards the best possible for himself in that moment and in that precise situation.

With the expression Encounter Group Rogers refers to the possibility of developing change, personal growth, through the exchange of one's experiences, one's own emotional experiences, through the expression of difficulties but also of resources.

Living a dimension of great freedom, the members of the group become more spontaneous, more flexible, more responsive to their feelings, more open to their experience, more strictly intimate and expressive in their interpersonal relationships. The only real learning is what each person carries out for himself, and it is only possible if the individual feels engaged in something meaningful that is based on experience and emotional involvement.

Rogers (1976) stated that people who fear change, those who exercise power in an authoritarian way, cannot love meeting groups, indeed they can only consider them dangerous, because they constitute experiences of authentic freedom that lead to a greater personal independence, to keep feelings less concealed, to a greater desire for innovation, to greater opposition to institutional rigidities.

While biological herd immunity follows the path of linear communication, psychological herd immunity will follow the path of collaboration, through recursive mechanisms of mutual reinforcement. In short, the possibility of elaborating ideas and sharing thoughts creates a contamination of resilience until reaching a sufficiently high number of people capable of positively supporting the social system with respect to the necessary change. 
If on the one hand herd immunity provides that a percentage of individuals in the population population, effectively preventing it from coming into contact with the pathogen, on the other hand the collaboration e connecting through practical or theoretical activities allows us to join forces to face together a difficult phase.

So, shifting this dynamic from the biological to the psychological, it is conceivable that a number of people who have developed their own way of making sense of the new way of being and living in the era of the coronavirus can be an element in itself facilitating towards those who struggle to adapt.

This generative dimension is already observable in those spontaneous or sought-after behaviours that we have often defined as resilient, oriented towards that sociality sought today through technological tools. Messenger, Whatsapp, Skype and social networks (Annarumma, \& Fragnito, 2014) become a new setting of live.

These groups are attuned to a greater desire and a strong emotional tension that derives from the authentic desire to intimately share a common feeling and which is perceived by all as a way of meaning. In this regard Jung (1999) argued: "Finding a sense, a meaning makes many things bearable.... perhaps all of them become bearable is [...] It is our task to seek that meaning that allows us to continue living each time or, if you prefer, to respond to our journey at every step". In short, the technological means is no longer the glittering tool that shows how original we are. But, on the contrary, it is the tool that allows us to be there, to process the uncertain situation and give it a new meaning, to perceive it as a further moment of change and uncertainty - perhaps more dramatic than usual, but absolutely authentic. The way to a new necessary change (Bateson, 2010).

\section{Conclusions}

Rogers believes that it is possible to get out of existential distress through contact with others. Sharing one's own discomfort, understanding and comparison make it possible to overcome one's discomfort. Rogers does not speak of group therapy but states that the group has the effect of a psychological stimulus to growth. It can be stated that these online groups are a tool full of potential and of radical changes in psycho-social dynamics.

It is a Copernican revolution that centres the user and his private life in the content production system. A revolution that requires an ethical reflection. According to Jenkins' Convergent Culture, we see grassroots media generating unpredictable dynamics. Grassroot convergence develops when it becomes easy for users to modify, expropriate and redistribute media content thanks to media convergence (operational logic of every culture that consists in enhancing the flow of content through media channels) and participatory culture (creation and circulation of new contents) and to collective and connective intelligence. Stephen Downes argues that even the world of education cannot escape the pervasive nature of the potential of the Web and its tools. Therefore, we must be aware that both the Web and its users have changed profoundly.

After all, it is from below that scientific and cultural revolutions are born historically, to the point of creating a sort of collective awareness, in fact the experience of collaboration demonstrates the extraordinary potential of help is inherent in ordinary people. At the time of COVID-19 everyone tries to provide their own representation, or interpretation, firm and precise, as if this could give us some certainty. A question can be raised: will there be a change? Will we come out changed? Let's think so, and it is possible will happen in countless ways.

\section{Note}

This scientific article is the result of a joint work by the authors. Felice Corona is author of the paragraph: Introduction to the dimension of uncertainty and social change. Maria Annarumma is author of paragraphs: The epochal change and the post covid paradigm, Shifting from the biological to the psychological immunity through collaboration and technology, Theoretical framework for future developments, Conclusions. 


\section{References}

Annarumma, M., \& Fragnito, R. (2014). ANTROPOMEDIA Web, Comunicazione, Formazione. [ANTROPOMEDIA Web, communication, education]. Aracne.

Bateson, M. C. (2010). Composing a further life: The age of active wisdom. Knopf.

Bauman, Z. (2000). Liquid society. Polity Press.

de Kerckhove, D. (1997). Connected intelligence: The arrival of the web society. Somerville House.

Downes, S. (2011). E-Learning 2.0 in eLearn Magazine. http://pulpnews.com/index.php

Jenkins, H. (2007). Cultura convergente [Convergent culture: Where old and new media collide]. Apogeo.

Jung, C. G. (1999). Jung parla. Interviste e incontri [Jung speaks. Interviews and meetings]. Adelphi.

Kuhn, T.S. (1979). La Struttura delle rivoluzioni scientifiche [The structure of scientific revolutions]. Einaudi.

Lévy, P. (1996). L'intelligenza collettiva. Per un'antropologia del cyberspazio [Collective intelligence: Mankind's emerging world in cyberspace]. Feltrinelli.

Lorenz, E. (2015). Predictability: Does the flap of a butterfly's wings in Brazil set off a tornado in Texas? Resonance. Journal of Science Education, 20(3), 260-263. https:/www.ias.ac.in/describe/article/ reso/020/03/0260-0263

Luhmann, N. (2005). Il paradigma perduto [The lost paradigm]. Il Saggiatore.

Lyotard, J.F. (1981). La condizione postmoderna [The postmodern condition]. Feltrinelli.

McWilliam, N. (2020). Psicoterapia durante una pandemia. https://www.oprs.it/psicoterapia-durante-unapandemia-nancy-mcwilliams/

Morin, E. (1993). La conoscenza della conoscenza [La Connaissance de la connaissance]. Feltrinelli.

Morin, E. (2008). Il Metodo [La Méthode]. Feltrinelli.

Popper, Karl R. (1973). Congetture e Confutazioni [Conjectures and refutations]. Il Mulino.

Rogers, C. (1972). Psicoterapia di consultazione [Counseling and psychotherapy. Newer concepts in practice]. Astrolabio.

Rogers, C. (1976). I Gruppi di Incontro [The encounter groups]. Astrolabio.

Rogers, C. (1983). Un Modo di Essere [A Way of being]. Martinelli.

Received: October 10, 2020

Accepted: December 11, 2020

Cite as: Annarumma, M., \& Corona, F. (2020). From fragmented certainty to post Covid paradigm: Resilient modalities based on group interaction supported by technologies. Problems of Psychology in the $21^{\text {st }}$ Century, 14(2), 87-92. https://doi.org/10.33225/ppc/20.14.87

\begin{aligned} \hline $\begin{array}{c}\text { Maria Annarumma } \\ \text { (Corresponding author) }\end{array} & \begin{array}{l}\text { PhD, Assistant Professor, Department of Human, Philosophical and } \\ \text { Educational Sciences, University of Salerno, Italy. } \\ \text { E-mail: mannarumma@unisa.it } \\ \text { Website: https://docenti.unisa.it/020320/en/home }\end{array} \\$\hline Felice Corona & $\begin{array}{l}\text { Full Professor, Department of Human, Philosophical and Educational Sciences, } \\ \text { University of Salerno, Italy. } \\ \end{array} \\ &$ E-mail: fcorona@unisa.it \\ & ORCID: https://orcid.org/0000-0002-3334-3566 \end{aligned}

